\title{
ANALISIS PERBANDINGAN KINERJA KEUANGAN PT. BANK BRI DAN PT. BANK MANDIRI PERIODE TAHUN 2010-2014 DENGAN MENGGUNAKAN RASIO KEUANGAN
}

\author{
Sindie Margaretha Loupatty ${ }^{1}$, Sifrid S. Pangemanan ${ }^{2}$, Heince R.N. Wokas ${ }^{3}$ \\ 1,2,3 Jurusan Akuntansi, Fakultas Ekonomi Dan Bisnis, Universitas Sam Ratulangi, Jln. Kampus Bahu, Manado, \\ 95115, Indonesia \\ E-mail : Sindiloupatty@gmail.com
}

\begin{abstract}
Company's financial performance can be seen from the aspect of financial ratios, such as LDR, CAR, ROA and ROE. The development of a company, can be seen and can be compared through the company's financial performance. This is certainly useful for investors, creditors, and owners to make profitable investment decisions. This study aims to determine the differences in financial performance of PT. Bank BRI Tbk (Bank BRI) and PT. Bank Mandiri Tbk (Bank Mandiri) by using financial ratio analysis. This research has used Independent analysis method of sample t-test. This research uses secondary data from Indonesia Stock Exchange. The result of the research shows that there are significant differences in financial performance between Bank BRI and Bank Mandiri. Suggestions for the Management should better improve the financial performance in order to attract the attention of investors, so as to maintain its predicate as a bank that has the greatest asset in Indonesia.
\end{abstract}

Keywords : : LDR, CAR, ROA, and ROE.

\section{PENDAHULUAN}

Bank adalah salah satu jenis usaha jasa perusahaan dibidang keuangan yang cukup berkembang dewasa ini. Juga merupakan jenis usaha yang sangat menarik untuk diketahui karena berkaitan dengan keuangan. Menurut Rose et.al (2008): A bank should be defined by what it does; in this case, banks are generally those financial institutions offering the widest range of financial services (sebuah bank harus didefinisikan apa adanya, dalam hal ini, Bank adalah institusi keuangan yang pada umumnya menawarkan jasa keuangan dalam lingkup yang luas). Bank merupakan lembaga intermediasi bagi pihak yang kelebihan dana dengan pihak yang kekurangan dana. Bagian keuangan berkaitan dengan banyak hal. Hal ini dapat dilihat pada Laporan Keuangan yang disajikan secara periodik dan terinci oleh bagian keuangan atau akuntansi suatu organisasi sangat penting untuk di analisis untuk mengetahui kemajuan dan sehat tidaknya suatu organisasi. Karena itu Laporan Keuangan sangat penting bagi setiap usaha, bahkan sebuah usaha kecilpun memiliki laporan keuangan dimana laporan tersebut menunjukkan semua aktivitas perusahaan dalam berbagai bentuk. Dengan demikian, pengelola keuangan dalam perusahaan hanya akan berhasil jika dia memiliki data-data lengkap tentang aktivitas perusahaan yang terjadi sehingga dapat menganalisa keuangan dan memberikan informasi yang tepat dan akurat mengenai keuangan perusahaan.

Kinerja perusahaan secara keuangan yang disajikan dalam laporan keuangan perlu dianalisis dengan alat analisa antara lain dengan menggunakan Rasio Keuangan. Menurut Sutrisno (2009: 14) Rasio Keuangan secara umum berkaitan dengan tiga aspek, yaitu aspek likuiditas, solvabilitas dan rentabilitas. Penggunaan Rasio Keuangan akan membantu menejer untuk melihat/menganalisis perkembangan/kinerja suatu perusahaan, membandingkan dengan kinerja keuangan perusahaan pada periode sebelumnya, atau dengan membandingkan kinerja keuangan dengan perusahaan pesaing, atau perusahaan sejenis dalam industri yang 
sama. Analisis kinerja keuangan perusahaan, menggunakan rasio keuangan, pada umumnya didasarkan pada laporan keuangan berupa Neraca dan Laporan Laba/Rugi. Dalam penelitian ini, peneliti hanya akan menganalisis kondisi keuangan perusahaan berdasarkan laporan keuangan yang umum disajikan. Para menejer keuangan pada umumnya membuat analisis keuangan berdasarkan laporan keuangan untuk memprediksi apakah perusahaan secara keuangan akan dapat bertahan atau akan memperoleh laba atau rugi pada periode berikutnya.

Penulis memilih obyek penelitian yaitu PT. Bank Mandiri Tbk dan PT. Bank BRI Tbk, sebagai sumber informasi dari penelitian. Bank-bank tersebut sengaja di pilih dengan beberapa alasan, yaitu bahwa PT. Bank Mandiri Tbk, adalah bank dimana gabungan (merger) beberapa bank milik pemerintah, dan yang memiliki aset terbesar dibandingkan dengan semua bank yang ada di Indonesia. Juga bank ini merupakan bank dengan kinerja dan pelayanan terbaik dalam beberapa tahun terakhir. Sedangkan PT. Bank BRI Tbk, merupakan bank yang beberapa Tahun terakhir ini meraup laba bersih hingga Triliun.

TABEL 1.1

TOTAL ASSETS DAN NET PROFIT

PT.Bank BRI Tbk dan PT.Bank Mandiri Tbk

Tahun 2010-2014

\begin{tabular}{|c|c|c|c|c|}
\hline \multirow{2}{*}{ PERIODE } & \multicolumn{2}{|c|}{ Total Assets } & \multicolumn{2}{c|}{ Net Profit } \\
\cline { 2 - 5 } & BRI & MANDIRI & BRI & MANDIRI \\
\hline $\mathbf{2 0 1 0}$ & 404.285 .602 & 449.774 .551 & 11.472 .385 & 9.218 .298 \\
\hline $\mathbf{2 0 1 1}$ & 469.899 .284 & 551.891 .704 & 15.087 .996 & 12.246 .044 \\
\hline $\mathbf{2 0 1 2}$ & 551.336 .790 & 635.618 .708 & 18.687 .380 & 15.504 .067 \\
\hline $\mathbf{2 0 1 3}$ & 626.182 .926 & 733.099 .762 & 21.354 .330 & 18.203 .753 \\
\hline $\mathbf{2 0 1 4}$ & 801.955 .021 & 855.039 .673 & 24.253 .845 & 19.871 .873 \\
\hline
\end{tabular}

\section{TINJAUAN PUSTAKA}

\subsection{Landasan Teori}

2.1.1 Definisi Akuntansi

Definisi Akuntansi Kata Akuntansi berasal dari bahasa Inggris yaitu Account yang berarti menghitung atau mempertanggung jawabkan dan kata Accountancy yang berarti halhal yang bersangkutan dengan sesuatu yang dikerjakan oleh Akuntan (Accountant). Akuntansi adalah seni pencatatan, penggolongan, dan peringkasan transaksi, dan kejadian yang bersifat keuangan dengan cara yang berdaya guna dan dalam bentuk satuan uang.

\subsubsection{Tujuan Akuntansi}

Tujuan akuntansi adalah menyediakan informasi tentang posisi keuangan, kinerja, serta perubahan posisi keuangan suatu perusahaan yang bermanfaat bagi sejumlah besar pemakai informasi akuntansi, dalam mengambil keputusan ekonomi.

\subsubsection{Pemakai Informasi Akuntansi}

Pemakai informasi akuntansi terbagi atas 7 (tujuh) bagian yaitu :

1. Investor

2. Karyawan

3. Pemberi Pinjaman (Kreditor)

4. Pemasok dan Kreditor Usaha Lainnya

5. Pelanggan

6. Pemerintah

7. Masyarakat 


\subsubsection{Pengertian Perbankan}

Pengertian bank menurut Kasmir: 2003 Bank secara sederhana dapat diartikan sebagai lembaga keuangan dimana kegiatan utamanya adalah menghimpun dana dari masyarakat serta menyalurkan kembali dana tersebut ke masyarakat serta memberikan jasa bank lain.

\subsubsection{Definisi Laporan Keuangan}

Laporan keuangan merupakan laporan tertulis yang memberikan informasi kuantitatif tentang posisi keuangan dan perubahan-perubahannya, serta hasil yang dicapai selama periode tertentu. Laporan keuangan dapat dijadikan media yang dapat dipakai untuk meneliti kondisi kesehatan perusahaan, dimana laporan keuangan tersebut terdiri dari neraca, perhitungan rugi laba, ikhtisar laba ditahan dan laporan posisi keuangan.

\subsubsection{Jenis-jenis Laporan Keuangan Bank}

Ada empat jenis laporan keuangan dalam akuntansi. Untuk mengetahui kondisi keuangan bisnis, Anda dapat mempelajari dan menggunakan laporan keuangan sebagai berikut :

1. Laporan Laba Rugi

2. Laporan Perubahan Modal

3. Neraca (Balance Sheet)

4. Laporan Arus Kas

\subsubsection{Kinerja Keuangan}

Menurut Sucipto (2003) pengertian kinerja keuangan adalah penentuan ukuran-ukuran tertentu yang dapat mengukur keberhasilan suatu organisasi atau perusahaan dalam menghasilkan laba.

\subsubsection{Rasio Keuangan}

James C V Horne dalam Kasmir (2008: 104) mengartikan rasio keuangan adalah indeks yang menghubungkan dua angka akuntansi yang diperoleh dengan membagi satu angka dengan angka lainnya.

\section{METODE PENELITIAN}

\subsection{Jenis penelitian}

Dalam penelitian ini jenis penelitian yang digunakan adalah Penelitian komparatif merupakan jenis penelitian deskriptif yang berusaha mencari jawaban secara mendasar mengenai sebab-akibat, dengan menganalisis faktor-faktor penyebab terjadinya maupun munculnya suatu fenomena atau kejadian tertentu. Penelitian komparatif merupakan penelitian yang sifatnya membandingkan, yang dilakukan untuk membandingkan persamaan dan perbedaan 2 atau lebih sifat-sifat dan fakta-fakta objek yang diteliti berdasarkan suatu kerangka pemikiran tertentu. Penelitian komparatif biasanya digunakan untuk membandingkan antara 2 kelompok atau lebih dalam suatu variabel tertentu.

\subsection{Tempat dan Waktu Penelitian}

Peneliti dalam hal ini, hanya menggunakan data sekunder saja berupa laporan keuangan tahunan dari perusahaan-perusahaan, PT Bank Bri Tbk dan PT Bank Mandiri Tbk. Waktu penelitian disesuaikan pada waktu setelah pelaksanaan studi literature, identifikasi masalah, perumusan masalah, tujuan dan manfaat penelitian yaitu mencakup keuangan, waktu, laporan keuangan 2010-2014.

\subsection{Metode pengumpulan}

\subsubsection{Data}

Didalam mendukung penelitian ini, maka jenis data yang dipakai yaitu data Kuantitatif. Data Kuantitatif merupakan data yang dapat di hitung atau berupa angka-angka. Dalam hal ini data laporan keuangan tahunan PT. Bank BRI Tbk dan PT. Bank Mandiri Tbk tahun 2010-2014. 


\subsubsection{Sumber data}

Data-data tersebut diperoleh dari data sekunder. Data sekunder adalah sumber data penelitian yang diperoleh peneliti secara tidak langsung melalui penggunaan media perantara (diperoleh dan dicatat oleh pihak lain), yaitu berupa dokumen laporan keuangan. Cara dan Teknik pengumpulan data yang digunakan adalah observasi dokumen, yaitu berupa laporan keuangan tahunan perusahaan yang terdaftar di Bursa Efek Indonesia atau www.idx.co.id dan informasi-informasi yang lain serta literatur lainnya.

\subsection{Populasi dan sampel}

Populasi adalah kelompok elemen yang lengkap, yang biasanya berupa orang, objek, transaksi, atau kejadian di mana kita tertarik untuk mempelajarinya atau menjadi objek penelitian (Kuncoro, 2009 : 118). Sampel adalah suatu himpunan bagian (subset) dari unit populasi. Populasi dan sampel dalam penelitian ini adalah laporan keuangan PT. BRI Tbk, dan laporan keuangan PT. Mandiri Tbk, yang diterbitkan selama lima tahun terakhir yaitu tahun 2010, tahun 2011, tahun 2012, tahun 2013, tahun 2014.

\subsection{Metode pengumpulan data}

Metode yang digunakan dalam penelitian ini adalah metode dokumentasi yaitu dengan cara mengumpulkan laporan keuangan yang telah dipublikasikan secara resmi oleh perusahaan. Metode Pengumpulan data yang digunakan dalam penelitian ini juga dengan studi kepustakaan yaitu penelitian yang dilakukan dengan cara mengumpulkan, mengklasifikasikan, dan menganalisis data tertulis yang di peroleh dari catatan yang terpublikasikan, buku teks, surat-surat dan artikel (Noor, 2014).

\subsection{Metode analisis}

Alat analisis yang digunakan berupa Rasio Keuangan sebagai dasar analisis perbandingan Kinerja Keuangan PT BRI Tbk, dan PT Mandiri Tbk dalam penelitian ini, menggunakan 7 (tujuh) Rasio keuangan, sebagai berikut :

\section{LDR (Loan to Deposits Ratio)}

LDR (Loan to Deposits Ratio) adalah rasio yang mengukur kemampuan bank dalam memenuhi kewajiban jangka pendek (bisa disebut likuiditas) dengan membagi total kredit terhadap total Dana Pihak Ketiga (DPK). Likuiditas perbankan perlu dikelola guna memenuhi kebutuhan saat nasabah mengambil dananya dan menyalurkan pinjaman (kredit) kepada peminjam (debitur). Jika nilai LDR terlalu tinggi, artinya perbankan tidak memiliki likuiditas yang cukup memadai untuk menutup kewajibannya terhadap nasabah (DPK). Sebaliknya, jika nilai LDR terlalu rendah berarti perbankan memiliki likuiditas yang cukup memadai tetapi mungkin pendapatannya lebih rendah, karena seperti yang diketahui dunia perbankan memperoleh pendapatan melalui kredit yang disalurkan. LDR dapat dihitung dengan cara:

\section{Total Kredit}

Loan to Deposit Ratio $=\frac{\text { Total Dana Pihak Ketiga }}{\text { x }} \quad 100 \%$




\section{CAR (Capital Adequacy Ratio)}

Untuk mencari rasio ini perlu terlebih dahulu diketahui besarnya estimasi resiko yang akan terjadi dalam pemberian kredit dan resiko yang akan terjadi dalam perdagangan surat-surat berharga. Rumus Untuk CAR sebagai berikut :

Equity Capital
Capital Adequacy Ratio $=\frac{\text { Total Loans }+ \text { Securities }}{} \times 100 \%$

3. ROA (Return On Assets)

ROA (Return On Assets) merupakan rasio yang mengukur kemampuan perbankan dalam menghasilkan profit atau laba (bisa disebut profitabilitas) dengan cara membandingkan laba bersih dengan sumber daya atau total aset yang dimiliki. Fungsinya adalah untuk melihat seberapa efektif perbankan dalam menggunakan asetnya dalam menghasilkan pendapatan. Semakin besar nilai ROA artinya semakin baik kemampuan perbankan dalam menghasilkan laba. Rumus untuk menghitung ROA yaitu :

EBIT
Return on assets $=\frac{\text { Total Aktiva }}{}$

\section{ROE (Return on Equity)}

Return on Equity yaitu kemampuan perusahaan dalam menghasilkan keuntungan dengan modal sendiri yang dimiliki, sehingga ROE ini ada yang menyebut sebagai rentabilitas modal sendiri. Laba yang diperhitungan adalah laba bersih setelah dipotong pajak atau EAT. Rumus untuk menghitung ROE yaitu:

Return on Equity $=\frac{\text { EAT (Laba bersih setelah pajak) }}{\text { Equity (Modal sendiri) }} \times 100 \%$

\subsection{Definisi operasional}

Definisi operasional merupakan informasi ilmiah yang sangat membantu peneliti lain yang ingin melakukan penelitian dengan menggunakan variabel yang sama.

\section{HASIL ANALISIS DAN PEMBAHASAN}

\subsection{Deskripsi objek penelitian}

\subsubsection{Gambaran Umum PT. Bank BRI Tbk}

Pada awalnya Bank Rakyat Indonesia (BRI) didirikan di Purwokerto, Jawa Tengah oleh Raden Aria Wirjaatmadja dengan nama Hulp-en Spaarbank der Inlandsche Bestuurs Ambtenaren atau Bank Bantuan dan Simpanan Milik Kaum Priyayi yang berkebangsaan Indonesia (pribumi). Berdiri tanggal 16 Desember 1895, yang kemudian dijadikan sebagai hari kelahiran BRI.

Pendiri Bank Rakyat Indonesia Raden Aria Wirjaatmadja Pada periode setelah kemerdekaan RI, berdasarkan Peraturan Pemerintah No. 1 tahun 1946 Pasal 1 disebutkan bahwa BRI adalah sebagai Bank Pemerintah pertama di Republik Indonesia. Adanya situasi 
perang mempertahankan kemerdekaan pada tahun 1948, kegiatan BRI sempat terhenti untuk sementara waktu dan baru mulai aktif kembali setelah perjanjian Renville pada tahun 1949 dengan berubah nama menjadi Bank Rakyat Indonesia Serikat. Pada waktu itu melalui PERPU No. 41 tahun 1960 dibentuk Bank Koperasi Tani dan Nelayan (BKTN) yang merupakan peleburan dari BRI, Bank Tani Nelayan dan Nederlandsche Maatschappij (NHM). Kemudian berdasarkan Penetapan Presiden (Penpres) No. 9 tahun 1965, BKTN diintergrasikan ke dalam Bank Indonesia dengan nama Bank Indonesia Urusan Koperasi Tani dan Nelayan.

Setelah berjalan selama satu bulan keluar Penpres No. 17 tahun 1965 tentang pembentukan Bank tunggal dengan nama Bank Negara Indonesia. Dalam ketentuan baru itu, Bank Indonesia Urusan Koperasi, Tani dan Nelayan (eks BKTN) diintegrasikan dengan nama Bank Negara Indonesia unit II bidang Rural, sedangkan NHM menjadi Bank Negara Indonesia unit II bidang Ekspor Impor (Exim).

Berdasarkan Undang-Undang No. 14 tahun 1967 tentang Undang-undang Pokok Perbankan dan Undang-undang No. 13 tahun 1968 tentang Undang-undang Bank Sentral, yang intinya mengembalikan fungsi Bank Indonesia sebagai Bank Sentral dan Bank Negara Indonesia Unit II Bidang Rular dan Ekspor Impor dipisahkan masing-masing menjadi dua Bank yaitu Bank Rakyat Indonesia dan Bank Ekspor Impor Indonesia. Selanjutnya berdasarkan Undang-undang No. 21 tahun 1968 menetapkan kembali tugas-tugas pokok BRI sebagai Bank Umum.

Sejak 1 Agustus 1992 berdasarkan Undang-undang perbankan No. 7 tahun 1992 dan Peraturan Pemerintah RI No. 21 tahun 1992 status BRI berubah menjadi PT. Bank Rakyat Indonesia (Persero) yang kepemilikannya masih 100\% ditangan Pemerintah.

PT. BRI (Persero) yang didirikan sejak tahun 1895 didasarkan pelayanan pada masyarakat kecil sampai sekarang tetap konsisten, yaitu dengan fokus pemberian fasilitas kredit kepada golongan pengusaha kecil. Hal ini antara lain tercermin pada perkembangan penyaluran KUK pada tahun 1994 sebesar Rp. 6.419,8 milyar yang meningkat menjadi Rp. 8.231,1 milyar pada tahun 1995 dan pada tahun 1999 sampai dengan bulan September sebesar Rp. 20.466 milyar.

Seiring dengan perkembangan dunia perbankan yang semakin pesat maka sampai saat ini Bank Rakyat Indonesia mempunyai Unit Kerja yang berjumlah 4.447 buah, yang terdiri dari 1 Kantor Pusat BRI, 12 Kantor Wilayah, 12 Kantor Inspeksi /SPI, 170 Kantor Cabang(Dalam Negeri), 145 Kantor Cabang Pembantu, 1 Kantor Cabang Khusus, 1 New York Agency, 1 Caymand Island Agency, 1 Kantor Perwakilan Hongkong, 40 Kantor Kas Bayar, 6 Kantor Mobil Bank, 193 P.POINT,3.705 BRI UNIT dan 357 Pos Pelayanan Desa.

\subsubsection{Gambaran Umum PT. Bank Mandiri Tbk}

Bank Mandiri merupakan bank yang telah beroperasi selama 15 tahun. Bank Mandiri adalah bank hasil upaya pemerintah merestrukturasi perbankan pasca krisis tahun 1998. Maka pada 2 Oktober 1998, Bank Mandiri resmi didirikan. Pada Juli 1999, empat bank milik pemerintah, yaitu Bank Ekspor Impor Indonesia, Bank Dagang Negara, Bank Bumi Daya, dan Bank Pembangunan Indonesia, digabungkan ke dalam Bank Mandiri. Keempat bank tersebut telah beroperasi di Indonesia dan mencatatakan sejarah perbankan Indonesia yang berawal dari 150 tahun yang lalu.

Bank Bumi Daya awalnya merupakan perusahaan Belanda De Nationale Handelsbank NV yang dinasionalisasi menjadi Bank Umum Negara pada tahun 1959. Kemudian pada tahun 1964, bank milik Inggris yaitu Chartered Bank juga dinasionalisasi, dan Bank Umum Negara diberikan hak untuk melanjutkan operasi bank tersebut. Setahun kemudian, Bank Umum Negara digabungkan ke dalam Bank Negara Indonesia dan berganti nama menjadi Bank Negara Indonesia Unit IV. Pada tahun 1968, beralih nama menjadi Bank Bumi Daya. 
Bank Dagang Negara awalnya bernama Nederlandsch Indische Escompto Maatschappij yang didirikan pada tahun 1857. Bank ini merupakan bank tertua di Indonesia yang berkedudukan di Batavia. Pada tahun 1949, namanya beralih menjadi Escomptobank NV yang kemudian pada tahun 1960 dinasionalisasi menjadi Bank Dagang Negara. Bank Dagang Negara merupakan bank pemerintah yang membiayai sektor industri dan pertambangan. Bank Ekspor Impor Indonesia bermula dari perusahaan dagang Belanda N.V Nederlansche Handels Maarschappij pada tahun 1827 dan di tahun 1870 berkembang di sektor perbankan. Kemudian pemerintah Indonesia menasionalisasi perusahaan ini pada tahun 1960 dan menggabungkan dengan Bank Negara Indonesia sehingga menjadi Bank Negara Indonesia Unit II. Pada tahun 1968, Bank Negara Unit II dipecah menjadi dua unit, salah satunya menjadi Bank Negara Indonesia Unit II Divisi Ekspor-Impor. Bank ini yang akhirnya menjadi Bank Ekspor-Impor Indonesia yang merupakan bank milik pemerintah yang membiayai kegiatan ekspor dan impor.

Bank Pembangunan Indonesia (Bapindo) awalnya merupakan Bank Industri Negara (BIN) yang merupakan bank industri yang berdiri tahun 1951. Misi BIN adalah mendukung perkembangan sektor ekonomi tertentu, yang berfokus pada perkebunan, industri, dan pertambangan. Pada tahun 1960, Bapindo dibentuk sebagai bank milik negara kemudian digabungkan dengan BIN. Bapindo membantu pembangunan nasional melalui pembiayaan jangka menengah dan jangka panjang pada sektor manufaktur, transportasi, dan pariwisata. Perjalanan sejarah keempat bank milik pemerintah tersebut yang kemudian digabungkan dalam Bank Mandiri pada Juli 1999 menjadi warisan tak ternilai bagi Bank Mandiri. Sejak berdirinya, Bank Mandiri meneruskan pelayanan jasa perbankan dan keuangan yang telah menjadi tonggak sejarah dengan pengalaman lebih dari 150 tahun yang berperan besar dalam pembangunan ekonomi Indonesia pasca krisis moneter tahun 1998.

Untuk dapat mempertahankan dan terus meningkatkan kinerjanya, Bank Mandiri melaksanakan transformasi lanjutan tahun 2010-2014, yaitu dengan melakukan revitalisasi visinya untuk "Menjadi Lembaga Keuangan Indonesia yang paling dikagumi dan selalu progresif". Dengan visi tersebut, Bank Mandiri mencanangkan untuk mencapai milestone keuangan di tahun 2014, yaitu nilai kapitalisasi pasar mencapai di atas Rp225 triliun dengan pangsa pasar pendapatan mendekati 16\%, ROA mencapai kisaran 2,5\% dan ROE mendekati $25 \%$, namun tetap menjaga kualitas aset yang direfleksikan dari rasio NPL gross di bawah 4\%. Pada tahun 2014, Bank Mandiri ditargetkan mampu mencapai nilai kapitalisasi pasar terbesar di Indonesia serta masuk dalam jajaran Top 5 Bank di ASEAN. Selanjutnya di tahun 2020, Bank Mandiri mentargetkan untuk dapat masuk dalam jajaran Top 3 di ASEAN dalam hal nilai kapitalisasi pasar dan menjadi pemain utama di regional. Untuk mewujudkan visi tersebut, transformasi bisnis di Bank Mandiri tahun 2010 akan difokuskan pada 3 (tiga) area bisnis yaitu:

Indikator keberhasilan tran sformasi lanjutan 2010-2014 ditunjukkan dengan pencapaian nilai kapitalisasi saham yang mencapai Rp254 triliun, Return on Asset mencapai 3,39\%, dan Non Performing Loan sebesar 2,17\%. Bank Mandiri telah berhasil mempertahankan predikat sebagai "the best bank in service excellence" selama 7 (tujuh) tahun berturut-turut dari Marketing Research Indonesia (MRI), dan mempertahankan predikat sebagai "Perusahaan Sangat Terpercaya" selama 7 (tujuh) tahun berturut-turut dari Indonesian Institute for Corporate Governance (IICG). 


\subsection{Hasil penelitian dan pembahasan}

Tabel 4.10

Ratio Keuangan PT. Bank BRI Tbk

Periode 2010-2014

\begin{tabular}{lccccc}
\hline & \multicolumn{2}{c}{ Rasio keuangan } & \multicolumn{2}{c}{ Periode } \\
& $\mathbf{2 0 1 0}$ & $\mathbf{2 0 1 1}$ & $\mathbf{2 0 1 2}$ & $\mathbf{2 0 1 3}$ & $\mathbf{2 0 1 4}$ \\
Loan to Deposit Ratio & $75,16 \%$ & $76,12 \%$ & $79,87 \%$ & $88,54 \%$ & $81,75 \%$ \\
Return On Assets & $3,68 \%$ & $3,99 \%$ & $4,32 \%$ & $4,45 \%$ & $3,84 \%$ \\
Return On Equity & $31,51 \%$ & $30,70 \%$ & $36,77 \%$ & $35,18 \%$ & $31,57 \%$ \\
Capital adequacy ratio & $14,84 \%$ & $17,45 \%$ & $18,50 \%$ & $18,26 \%$ & $19,74 \%$ \\
\hline
\end{tabular}

Sumber : Laporan Keuangan (Data diolah)

Berdasarkan hasil perhitungan rasio Loan to Deposit Ratio PT. Bank BRI 2010 sampai dengan 2014 berada dalam kondisi yang sehat atau aman. Dimana nilai ideal rasio ini Loan to Deposit Ratio minimum 75\% < LDR $\leq 85 \%$ masih dalam kondisi baik/sehat.

Berdasarkan hasil perhitungan rasio Return On Assets PT. Bank BRI 2010 sampai dengan 2014 berada dalam kondisi yang sehat atau aman. Dimana nilai ideal rasio Return On Assets ROA > 1,22\% (Sangat baik).

Berdasarkan hasil perhitungan Return On Equity PT. Bank BRI tahun 2010 sampai dengan tahun 2014 berada dalam kondisi sehat/aman dimana nilai ideal dari rasio ini ROE > $15 \%$ (Sangat baik).

Berdasarkan hasil perhitungan Capital adequacy ratio PT. Bank BRI tahun 2010 sampai dengan tahun 2014 berada dalam kondisi sehat/aman dimana nilai ideal dari rasio car yaitu $C A R \geq 12 \%$ (Sangat memadai).

\section{KESIMPULAN DAN SARAN}

\subsection{Kesimpulan}

Berdasarkan hasil perhitungan rasio keuangan peiode 2010-2014, hasil penelitian ini adalah :

1. Kinerja keuangan PT. Bank BRI Tbk dari tahun 2010-2014 berada dalam kondisi yang baik/sehat. Namun pada rasio Loan to Deposit Ratio dan Capital Adequacy Ratio tingkat yang lebih likuid berada pada PT Bank Mandiri.

2. Dari perhitungan dengan menggunakan rasio Loan to Deposit Ratio pada PT. Bank BRI dan PT. Bank Mandiri berdasarkan perbandingan antara kedua bank yaitu tingkat likuiditas yang lebih likuid berada pada posisi Bank Mandiri.

3. Dari perhitungan dengan menggunakan rasio Return On Assets pada PT. Bank BRI dan PT Bank mandiri berdasarkan perbandingan antara kedua bank yaitu tingkat yang lebih mendapatkan profit/laba yaitu PT. Bank BRI

4. Dari perhitungan dengan menggunakan rasio Return On Equity pada PT. Bank BRI dan PT. Bank Mandiri berdasarkan perbandingan antara kedua bank yaitu tingkat yang lebih menguntungkan dengan modal sendiri dan yang mendapatkan profit/laba berada pada posisi bank BRI yang profitnya lebih meningkat.

5. Dari perhitungan dengan menggunakan rasio Capital Adequacy Ratio pada PT. Bank BRI dan PT Bank mandiri berdasarkan perbandingan antara kedua bank yaitu berada pada posisi PT. Bank Mandiri berarti tingkat kemampuan perbankan semakin baik dalam menghadapi kemungkinan resiko kerugian dibandingkan dengan PT. Bank BRI.

\subsection{Saran}

Berdasarkan kesimpulan yang telah didapat, saran bagi pihak manajemen Bank BRI dan Bank Mandiri sebaiknya meningkatkan kinerja keuangan agar dapat menarik perhatian para investor, sehingga dapat mempertahankan predikatnya sebagai bank yang memiliki asset 
terbesar di Indonesia. Karena kinerja keuangan perusahaan yang baik membuat para investor tidak akan ragu dalam memilih perusahaan mana mereka akan berinvestasi. Sebab para investor akan memilih perusahaan yang terbaik dalam menanamkan modalnya. Diharapkan agar hasil penelitian ini dapat digunakan sebagai bahan acuan untuk melakukan penelitian lainnya yang berhubungan dengan variabel atau objek penelitian ini. Serta diharapkan penelitian ini dapat dikembangkan lewat ilmu pengetahuan dibidang keuangan.

\section{DAFTAR PUSTAKA}

Ana. S., 2016. Analisis Perbandingan Kinerja Keuangan Bank Umum Konvensional dan Bank Umum Syariah Di Indonesia (Studi Pada Perusahaan Perbankan Yang Terdaftar Di Bank Indonesia Tahun 2010-2014). Universitas Lampung, Bandar Lampung. Di akses 17 April 2018

Cahrles T.Horngren dan Walter T.Harrison.2007.Akuntansi Jilid 1, Edisi ke-7.Jakarta: Penerbit Erlangga.

Fahmi, Irham. 2013. "Pengantar Manajemen Keuangan". Bandung

Franklin. J. P., 2015. Perbandingan Kinerja Keuangan Pada PT Bank Mandiri Tbk, PT Bank Central Asia Tbk, dan PT Bank CIMB Niaga Tbk Menggunakan Rasio Keuangan, Fakultas Ekonomi Dan Bisnis, Jurusan Manajemen Universitas Sam Ratulangi, Manado. Diakses 17 April 2018

Husnan, Suad 2012. Dasar-Dasar Manajemen Keuangan. Edisi. Keenam. Cetakan Pertama. Yogyakarta: UPP STIM YPKN. Ikatan Akuntansi Indonesia (IAI)

Horne, James C. Van dan John M Wachowicz, Jr. 2012. Prinsip-prinsip. Manajemen Keuangan (Edisi 13). Jakarta

Husein. S. R., 2012. Analisis Perbandingan Kinerja Keuangan Bank Muamalat Indonesia (BMI) Dengan Bank Syariah Mandiri (BSM). Sekolah Tinggi Ilmu Ekonomi Perbanas, Surabaya. Di akses 17 April 2018

http//www.bankbri.co.id. Di akses 18 April 2018

http//www.idx.co.id. Di akses 18 April 2018

Ikatan Akuntan Indonesia. 2007. "Standar Akuntansi Keuangan". Jakarta: Salemba Empat.

Ikatan Akuntansi Indonesia, 2009, Standar Akuntansi Keuangan, PSAK No. 1 : Penyajian Laporan keuangan. Jakarta : Salemba Empat.

Kasmir. 2003. Bank Dan Lembaga Keuangan lainnya. Jakarta

Kasmir, 2008, Analisis Laporan Keuangan, Rajawali Pers, Jakarta.

M. Sadeli, lili, 2002. Dasar-dasar Akuntansi, PT. Bumi Aksara, Jakarta.

Munawir, S. 2012. Analisis Informasi Keuangan, Liberty, Yogyakarta

Maliangan S., 2014. Analisis Perbandingan Kinerja Keuangan Antara PT. Bank Central Asia Tbk dan PT.Bank Cimb Niaga Tbk. Fakultas Ekonomi Dan Bisnis, Jurusan Manajemen Universitas Sam Ratulangi, Manado. Diakses 17 April 2018

Nazir, Moh. 2005. Metode Penelitian. Jakarta: Ghalia Indonesia

Profil perusahaan ., http//www.bankmandiri.co.id. Di akses 18 April 2018

Rumondor F. R., 2013. Perbandingan Kinerja Keuangan Bank Mandiri, BRI dan BNI Yang Terdaftar Di Bursa Efek Indonesia. Fakultas Ekonomi dan Bisnis, Jurusan Manajemen Universitas Sam Ratulangi, Manado. Diakses 18 April 2018

Rollando M.F. Mamahit., 2016. Analisis Perbandingan Kinerja Keuangan Bank Milik Pemerintah Dengan Bank Milik Swasta Nasional Di Indonesia (Periode 2009-2014). Fakultas Ekonomi dan Bisnis, Jurusan Manajemen Universitas Sam Ratulangi, Manado. Diakses 23 Mei 2018

Sutrisno. (2009), Manajemen Keuangan Teori, Konsep dan Aplikasi, Edisi Pertama, Cetakan. Ketujuh, Penerbit Ekonisia, Yogyakarta. 
Smith dan Skousen. 1995. Akuntansi Intermediate. Jilid 2. Edisi Kedelapan. Erlangga. Jakarta.

Susilo Sri Y., Sigit Triandaru, Totok Budi Santoso, 2006, Bank dan Lembaga Keuangan Lain, Jakarta. : Salemba Empat.

Sucipto. 2003. "Penilaian Kinerja Keuangan.” Jurnal Akuntansi. Universitas Sumatra. Utara. Medan.

Srimindarti, 2006. Balanced Scorecard Sebagai Alternatif untuk Mengukur Kinerja. Semarang: STIE Stikubank.

Yogyakarta. Noor, Juliansyah. 2014. Metodologi Penelitian. Kencana. Jakarta.

Yves Regina Mewengkang., 2013. Analisis Perbandingan Kinerja Keuangan Bank Pemerintah dan Bank Umum Swasta Nasional Yang tercatat di BEI. Fakultas Ekonomi dan Bisnis, Jurusan Manajemen Universitas Sam Ratulangi, Manado. Di akses 23 Mei 2018 